Technological University Dublin

DƯBLIN

ARROW@TU Dublin

2008-05-01

\title{
Towards a Model of Critical Ethics to Inform the Research Process in Postgraduate Research
}

Aidan Kenny

Technological University Dublin, aidan.kenny@tudublin.ie

Follow this and additional works at: https://arrow.tudublin.ie/cserart

Part of the Educational Assessment, Evaluation, and Research Commons

\section{Recommended Citation}

Kenny, A. (2008). Towards a Model of Critical Ethics to Inform the Research Process in Postgraduate Research.Level3, no.6. May, 2008. doi:10.21427/D79G8V

This Article is brought to you for free and open access by the Centre for Social and Educational Research at ARROW@TU Dublin. It has been accepted for inclusion in Articles by an authorized administrator of ARROW@TU Dublin. For more information, please contact arrow.admin@tudublin.ie, aisling.coyne@tudublin.ie, gerard.connolly@tudublin.ie.

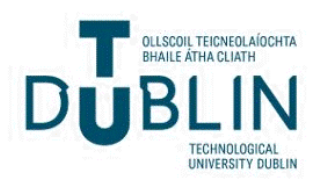


Dublin Institute of Technology

ARROW@DIT

2008-05-01

\section{Towards a model of critical ethics to inform the research process in postgraduate research}

Aidan Kenny

Dublin Institute of Technology

\section{Recommended Citation}

Kenny, Aidan, "Towards a model of critical ethics to inform the research process in postgraduate research" (2008). Articles. Paper 1. http://arrow.dit.ie/dirreart/1 


\title{
Towards a model of critical ethics to inform the research process in postgraduate research
}

\author{
Aidan Kenny \\ DIT
}

Acknowledgements

I would like to thank Dr Anne Murphy and the editors and peer reviewers of DIT Level 3 for the kind advice, and colleagues in DIT who gave me comments on previous drafts of this paper.

\begin{abstract}
The ethics narrative has become embedded in the contemporary research process, as is evident in the emergence of Ethical Committees in faculty and both public and private organisations. Ethics have been codified, made visible and accessible as text artefacts in the forms of (both voluntary and regulatory) codes, statements, conventions, guidelines, principles, procedures, practices. In this short paper I explore this codification of ethics from the period after the Second World War, detailing some of the milestone text artefacts. I note the case of ethics in social science research and the professions, and then focus on ethics in educational research. Finally I deliberate on the practical application and considerations for my own Doctor in Education (D.Ed.) research in Trinity College Dublin (TCD), suggesting a critical ethics model that aligns well with my current research and scholarship process. The rationale for this latter section is that it might serve as an indicator for novice researchers at postgraduate level towards developing a critical ethical positionality to inform research methodology and methods.
\end{abstract}

\section{The significance of the Nuremberg Code}

The Nuremberg Code, developed after the Second World War, dealt particularly with research on, or with, human subjects. A key tenet of that code is that the voluntary consent of the human subject in any research is absolutely essential. A relevant extract from the Nuremberg Code with regards to voluntary consent is as follows.

(1) The voluntary consent of the human subject is absolutely essential.

This means that the person involved should have legal capacity to give consent; should be so situated as to be able to exercise free power of choice, without the intervention of any element of force, fraud, deceit, duress, over-reaching, or other ulterior form of constraint or coercion; and should have sufficient knowledge and comprehension of the elements of the subject matter involved, as to enable him to make an understanding and enlightened decision. This latter element requires that, before the acceptance of an affirmative decision by the experimental subject, there should be made known to him the nature, duration, and purpose of the experiment; the method and means by which it is to be conducted; all inconveniences and hazards reasonably to be expected; and the effects upon his health or person, which may possibly come from his participation in the experiment.

The duty and responsibility for ascertaining the quality of the consent rests upon each individual who initiates, directs or engages in the experiment. It is a personal duty and responsibility, which may not be delegated to another with impunity.

(Nuremberg Code 1949) 
During the Nuremberg War Crime Trials legal representatives acting on behalf of the Allied Forces sought to expose the full extent of the systematic acts of cruelty, brutality, torture, enslavement, starvation, and mass murder perpetrated by members and associates of the Nazi regime. Within the evidence that emerged during the trials and not withstanding the horror of the 'Final Solution', ${ }^{[1]}$ the strategic plan was to efficiently and effectively annihilate what the Nazis viewed as lesser races or sub humans, specifically Jews, Gypsies and other minority groupings then living in Germany and the countries it controlled. Details surfaced which chronicled numerous research programmes developed by scientists, physicians and supported by politicians, industrialists and the military. This evidence led to a separate trial in 1947 with 23 leading scientists and physicians being charged with war crimes. The charges were stark and horrific the trial records ${ }^{[2]}$ listed the experiments as 'crimes committed in the guise of scientific research', which included 'high-altitude experiments; freezing experiments; malaria experiments; mustard gas experiments; Ravensbrueck experiments concerning sulfanilamide and other drugs, bone, muscle, and nerve regeneration and bone transplantation; seawater experiments; epidemic jaundice; sterilization experiments; typhus and related experiments; poison experiments; incendiary bomb experiments; and Jewish skeleton collection', 'crimes of mass extermination', 'murder of Polish nationals' and 'euthanasia'. It was suggested by some of the accused that the warrant for these experimentations and research was the pursuit of scientific knowledge, the advancement of medical practice, which would assist understanding and help in the development of procedures and cures, and would benefit humanity. As a result of the unearthing of this evidence which depicts the vile abuses perpetrated by the Nazi regime, the deplorable treatment of human subjects by scientists and physicians in their research experiments, prominent members of the Allied Forces proposed the Nuremberg Code (1949) in order to provide a mechanism that captured the learning from the trials which gave a clear international set of principles to inform future research and experimentation on human subjects.

The guiding principles of the Nuremberg Code - namely voluntary consent, informed consent, right to withdraw, avoidance of harm and suffering, duty and responsibility of the researcher to the participant, the expertise and qualifications of the researcher - are reflected in contemporary codes of professional practice and ethical guidelines. Other organisations that emerged after the Second World War which have had international influence and published substantial material on the appropriate treatment of humans are The United Nations Organisation Charter, which was formally signed by 50 nations in 1945; the Universal Declaration of Human Rights $^{[3]}$ approved by the UN Assembly in 1948; The Council of Europe, founded in 1949 under the London Treaty, with ten original members (including Ireland) which published the Convention for Human Rights and Fundamental Freedoms ${ }^{[4]}$ in 1950.

These important international documents have served as the primary background texts utilised by various governments, policy-makers, funders and professional associations to inform their codes of practice and ethical guidelines in relation to research on human subjects. For example the World Medical Association (WMA) directly incorporated the 10 principles from the Nuremberg Code into their Helsinki Declaration ${ }^{[5]}$ on Human Experimentation in 1964; the declaration has since been revised on five occasions, with the latest in 2000. The most recent area of ethical concern in the medical and bio-medical fields is genetics and research into cloning, stem cell, eugenics, pharmacogenetics, DNA data, and the unravelling of the human 
genome. International organisations, professional bodies, human rights organisations, religious organisations, industry and other interested parties are lobbying and exerting pressure on governments to pass laws in order to regulate the types of research that can occur in this emerging area. ${ }^{[6]}$

\section{Research ethics in the social sciences}

The incorporation of ethical guidelines into professional associations is evident in the social science domain. Sarantakos (1998: 21) notes the American Association of Public Opinion Research (AAPOR) adopted a 'Code of Professional Ethical Practice' in 1977, The Australian Psychologist Society (APS) incorporated ethical guidelines into its 'Code of Professional Practice' in 1986 and the Australian Vice-Chancellors Committee produced the 'Guidelines for Responsible Practices in Research and Dealing with Problems of Misconduct' in 1990. Busher (2002: 75) lists the following professional bodies located in the UK that have adopted codes of ethics: British Psychological Society (BPS) 'Code of Conduct for Psychologists' 1993; British Sociological Association (BSA) 'Statement of Ethical Practice' 1992; British Educational Research Association (BERA) 'Ethical Guidelines' 1994. From a brief review of these documents several commonalities can be identified. Some of these can be traced back to principles inherent in the Nuremberg Code. For a typology ${ }^{[7]}$ of other similarities see Table 1. 
Level3 - May 2008 -Issue 6

Table 1 A typology depicting commonalities between different research codes of ethics

\begin{tabular}{|c|c|c|c|}
\hline Nuremberg Code & BPS Code & BSA Statement & BERA Guidelines \\
\hline Voluntary, informed consent & $\begin{array}{l}\text { Valid consent of participants, ensuring that } \\
\text { participants are adequately aware and } \\
\text { understand the nature of the investigation }\end{array}$ & Freely given informed consent & $\begin{array}{l}\text { Informed consent, participants } \\
\text { should be made aware of the aims, } \\
\text { purposes and consequences of the } \\
\text { research }\end{array}$ \\
\hline $\begin{array}{l}\text { Avoid all unnecessary } \\
\text { physical and mental injury }\end{array}$ & $\begin{array}{l}\text { Ensure research participants' interests are } \\
\text { safeguarded; act within the law, the welfare of } \\
\text { recipients is paramount }\end{array}$ & $\begin{array}{l}\text { Responsibility to ensure the physical, } \\
\text { social and psychological well being of } \\
\text { participants }\end{array}$ & $\begin{array}{l}\text { Responsibility to be mindful of } \\
\text { cultural, gendered, religious and } \\
\text { other significant differences within } \\
\text { the research population }\end{array}$ \\
\hline $\begin{array}{l}\text { Experiment undertaken by a } \\
\text { scientifically qualified person }\end{array}$ & $\begin{array}{l}\text { Psychologist should endeavour to maintain and } \\
\text { develop their professional competence }\end{array}$ & $\begin{array}{l}\text { Have the necessary skill and training to } \\
\text { carry out the research, recognise their } \\
\text { boundaries }\end{array}$ & $\begin{array}{l}\text { Operate within the ethic of respect } \\
\text { for persons directly or indirectly } \\
\text { involved in the research }\end{array}$ \\
\hline \multirow{7}{*}{$\begin{array}{l}\text { Human subject has the liberty } \\
\text { to end the experiment at any } \\
\text { stage }\end{array}$} & $\begin{array}{l}\text { Uphold the rights of recipients of services to } \\
\text { withdraw consent }\end{array}$ & $\begin{array}{l}\text { Research participants made aware of } \\
\text { their right to refuse to participate }\end{array}$ & $\begin{array}{l}\text { Participants have the right to } \\
\text { withdraw from the study at any time }\end{array}$ \\
\hline & $\begin{array}{l}\text { Take all reasonable steps to preserve the } \\
\text { confidentiality of information }\end{array}$ & $\begin{array}{l}\text { Participants should be afforded } \\
\text { anonymity and confidentiality }\end{array}$ & $\begin{array}{l}\text { Responsibility to protect the } \\
\text { confidentiality of participant and data }\end{array}$ \\
\hline & $\begin{array}{l}\text { Maintain adequate records, ensuring privacy, } \\
\text { subject to the requirements of the law }\end{array}$ & $\begin{array}{l}\text { Data storage, dissemination, } \\
\text { publication should be in accordance } \\
\text { with the law }\end{array}$ & $\begin{array}{l}\text { Data results belong to the researcher, } \\
\text { they should take adequate precaution } \\
\text { to protect data }\end{array}$ \\
\hline & $\begin{array}{l}\text { Uphold the rights of those whose capacity to } \\
\text { give valid consent to interventions may be } \\
\text { diminished }\end{array}$ & $\begin{array}{l}\text { Research involving vulnerable people, } \\
\text { especially children requires particular } \\
\text { care }\end{array}$ & $\begin{array}{l}\text { Care should be taken when } \\
\text { interviewing children and students, } \\
\text { permission needed from parent and } \\
\text { school }\end{array}$ \\
\hline & $\begin{array}{l}\text { Refrain from making exaggerated, sensational } \\
\text { and unjustifiable claims }\end{array}$ & $\begin{array}{l}\text { Report findings accurately and } \\
\text { truthfully }\end{array}$ & $\begin{array}{l}\text { Accurate reporting of findings, no } \\
\text { deliberate falsification, plagiarism }\end{array}$ \\
\hline & $\begin{array}{l}\text { In their work psychologists shall conduct } \\
\text { themselves in a manner that does not bring into } \\
\text { disrepute the discipline and the profession of } \\
\text { psychology }\end{array}$ & $\begin{array}{l}\text { Member should strive to maintain the } \\
\text { integrity of sociological inquiry as a } \\
\text { discipline }\end{array}$ & $\begin{array}{l}\text { Protect the integrity and reputation of } \\
\text { educational research by ensuring } \\
\text { they conduct their research to the } \\
\text { highest standards }\end{array}$ \\
\hline & $\begin{array}{l}\text { Be mindful of external interests trying to } \\
\text { influence or direct the reporting of research }\end{array}$ & $\begin{array}{l}\text { Clarify the obligations, roles and } \\
\text { interests of researcher, funder institute, } \\
\text { etc. from the start }\end{array}$ & $\begin{array}{l}\text { Should not engage in research that } \\
\text { conflicts with academic freedom }\end{array}$ \\
\hline
\end{tabular}


It is interesting to note that all three examples are based on 'voluntary' implementation of the code, convention and guidelines by members of the different associations. As such the onus is placed on the individual members to act in a professional and proper manner and to give due consideration to the traditions, expertise and expectations of each particular discipline (psychology, sociology and education). Each of these documents encourages a collegial culture of peer review with support systems and processes in place for members. This leans towards a form of professional self-regulation of the research activities of members of the discipline. However, in all cases there was a mention that investigations, research and inquiries should be mindful of the 'law' and indeed not act contrary to it. This is important, as it adds an external control mechanism to modulate the inherent interests of the specialised knowledge, inquiry and curiosity of the individual disciplines into the broader socio-political reality of civil society. Of course there are power dynamics present here between the interests of capital, science and society, with powerful 'elites' and interest groups vying to regulate (for either economic or moral reasons) ${ }^{[8]}$ the freedom of scientific research. Stem cell research is one such case where some science research centres need substantial financial investment to carry out their research. Certain capital interests are willing to invest large resources in this research because of potential projected returns, and some civil and religious groups are campaigning against stem cell research on ethical and moral grounds.

These 'elites' and interest groups are lobbying for legislative, binding regulation, which has international standing and can afford some protection to their respective positions. This seems to be in contrast to the self-regulation assertions of the professional associations, who want to rely on the internal discipline-specific expertise to make judgements based on mechanisms such as peer review and ethics committees. This form of self-regulation positions the 'locus of control' firmly within the professional discipline, and gives some protection to the notion of 'freedom of inquiry' and acts as a buffer zone against external vested interests.

Cohen et al. (2004: 56) suggest that social scientists have a responsibility to both their discipline and to the subjects of their research. Fundamental to this duty is the respect for the dignity of the human subject ${ }^{[9]}$ and the quest for truth and knowledge. They caution that ethical guidelines are not 'definitive' but rather they should be applied in context, with professional considerations and the value judgements of the benefit of the research. They note that this leads to 'sources of tension' between the 'absolutists', who argue that the code of ethics should be strictly adhered to, with no room for deviation, and the 'relativists', who argues for leeway based on the context of the research and the personal judgement of the professional researcher. The argument here centres on the notion of scientific research freedom, and whether the interests of society and the greater good are best served by applying full legally binding regulation on scientific inquiries or by accepting self and peer review based on expert professional judgement. Although this question in itself adopts an absolutist approach, seeking a decision either way, it leaves out the complexity of the research process and the creative engagement with the unknown, the necessary risk taking and the questioning of 'perceived wisdom'. 
Howe and Moses (1999) offer an interesting perspective suggesting two dominant approaches to research ethics, the 'traditional' and the 'contemporary': The 'traditional' approach to research ethics is characterised by the distinct separation of the scientific merits from the moral, political and social domain (questions). In essence the proposition is that this distancing increases the neutrality of scientific inquiry thereby adding to the validity of the research process. This approach is most associated with experimental, medical or what is generally termed as the 'quantitative' research paradigm. In contrast, the 'contemporary' approach places the social at the heart of research ethics, the engagement with and within the sociopolitical and moral discourse, giving consideration to the culture, beliefs, norms, gender, traditions, and social structures of the research environment. The notion of creating a distance between researcher and subject is rejected and replaced with a negotiated process, which occurs in a social context and as such is 'value laden'. The scientist/researcher does not seek to operate in a social space removed from human society, but rather accepts the social context, the political and moral engagement, and endeavours to construct an appropriate research ethics process, that is sensitive to the social phenomenon and informed by the specific discipline's theory and practice. This type of research approach is mostly associated with what has been generally termed as the 'qualitative' research paradigm. ${ }^{[10]}$

\section{Research ethics in education research}

As Pring (2001: 407) notes, 'Educational researchers are becoming increasingly conscious of the ethical dimension of their research'. He highlights two practical examples to reinforce his statement. The members of both the American Educational Research Association (AERA) estimated at 25,000, ${ }^{[1]}$ and the British Education Research Association (BERA) estimated at 2,356 ${ }^{[12]}$ have adopted (and regularly updated) codes of conduct and ethical guidelines for educational researchers. Of course there are other examples of education research focused associations that have codes of ethics in place, such as the Australian Association of Educational Researchers (AAER), and the individual national associations involved with the European Educational Research Association (EERA) which counts 20 European national associations in its membership ${ }^{[13]}$ including the Educational Studies Association of Ireland (ESAI). The emergence of education research associations seems to be unevenly distributed over the last century ${ }^{[14]}$. While the American ERA claims to have been founded in 1916, the other associations seem to have emerged after the Second World War: France in 1945, then gradually from the 1960s onwards, Germany in 1964, Australia in 1970, Netherlands in 1975, Switzerland in 1975 and Finland in 1978, with a further clustering of newly formed associations in the 1990s, Britain, Portugal and the Czech Republic in 1990, Spain in 1994, Lithuania in 1999, and then Slovakia in 2001, Ireland in 2002, and Scotland in 2003. These examples show there is a clear trend for educational researchers to group together and establish national associations in the interest of promoting and developing educational research. In nearly all the ERA web-based Homepages that were searched, there were hyperlinks leading to documents relating to research ethics. These documents varied in size from two pages to 43 pages. It would seem that Pring's (2001) statement holds currency when tested on a limited web search of ERAs, but what about Higher Education Institutes in Ireland (HEI)? Do they have research ethics codes in place? 


\section{Visibility of research ethics in Irish Higher Education Institutes}

To explore the visibility of the research ethics material in HEIs that is publically available through electronic resources, a brief keyword search run was made on the 7 February 2008. The focus of the keyword search was the public access websites of the seven Irish universities, the 13 Institutes of Technology (IoTs) and the DIT. These make up the majority of publically funded HEIs in Ireland. ${ }^{[15]}$ The search procedure involved opening up the homepage of each HEI and utilising the search facility provided. Three keyword searches were used: (1) 'research ethics'; if nothing surfaced then enter (2) 'ethics committee'; if nothing surfaced then enter (3) 'ethics'. Each hit was explored separately looking for further linkages and documents. The results of this brief online search (presented in Table 2) revealed that most of these HEIs had a specific ethics document relating to research. In the universities, the DIT and two of the IoTs, Ethic Committees were established and guidelines for making a research submission were provided. While some of the IoTs did not have institutional research ethics documents they did have ethics as an item included in some subject programme documents and in one case as part of their procurement policy. Also it is worth noting that some disciplines seem to have more documents and a greater level of complexity and rigorous procedures relating to research ethics and research project submissions, for example medical, medicines, and engineering. 


\section{Level3 - May 2008 -Issue 6}

Table 2 Results from keyword searches (Ethics, Research Ethics, Ethics Committee) of HEI public access websites on 7 February 2008

Visibility mapping out exercise of Irish Higher Education Institutes (HEIs) research ethics codes, statements, policies, procedures and practices

Higher Education Institutions in Ireland

Athlone Institute of Technology

Cork Institute of Technology

Dublin City University

Dublin Institute of Technology

Dundalk Institute of Technology

Dun Laoghaire Institute of Art \& Design Technology

Galway Mayo Institute of Technology

Institute of Technology Tralee

Institute of Technology Blanchard Town

Institute of Technology Carlow

Institute of Technology Sligo

Institute of Technology Tallagh

Limerick Institute of Technology

LetterKenny Institute of Technology

University College Cork

University College Galway

NUI Maynooth

Trinity College Dublin

University College Dublin

University of Limerick

Waterford Institute of Technology
Search results and URL link or website address

No relevant document found during this search www.ait.ie

No relevant document found during this search www.cit.ie

Ethics Committee 'Guideline on Best Practice in Research Ethics' http://tinyurl.com/2u4ybr

Research Ethics Committee 'Guiding Principles' http://tinyurl.com/2x995z

No relevant document found during this search www.dkit.ie

Procurement Policy 'Code of Ethics', p. 17 http://tinyurl.com/ysghjg

Academic Code of Practice, No. 5: Research http://tinyurl.com/2mi3q3

Terms of Reference Research Committee http://tinyurl.com/37k2gr

No relevant document found during this search www.itb.ie

No relevant document found during this search www.itcarlow.ie

Research Handbook http://tinyurl.com/yp2fez

Ethics committee mentioned but could not locate ethics document http://www.ittdublin.ie/ResearchatITTDublin

No relevant document found during this search www.lit.ie

No relevant document found during this search www.lyit.ie

Ethics committee 'An Introduction to Research Ethics' http://tinyurl.com/ywcl8y

Ethics Committee 'Standard Operating Procedures Research Ethics committee' http://tinyurl.com/3yoacp

Ethics Committee 'Ethical Review \& Research Integrity General Policy Statement' http://tinyurl.com/22kpqw

Ethics Committee 'Good Research Practice' http://tinyurl.com/32zm2s

Ethics Committee 'Ethics Code and Good Practice' http://tinyurl.com/yqfyvy

Research Ethics Committee 'Guidelines Application' http://tinyurl.com/39a5yf

'Procedures for the Implementation of the Code of Conduct for Responsible Practice in Research' http://tinyurl.com/2pz4fb 
The universities seem to have had their research ethics procedures in operation for a considerably longer period of time than DIT and the IoTs; most of the IoT documents were dated in the last three years, while the DIT's Ethics Committee was established in 2001. The results from this search are based on information obtained from public access websites. In the two cases of Maynooth and DCU the general ethics committee page could be accessed and all the hyperlinks to documents were password protected. Also it should be borne in mind that some HEIs may have hard copy research ethics documents that have not been transferred into electronic format and therefore were not accessible during this search. The main purpose of this website search was to map out the visibility of documents relating to research ethics, in terms of codes, guidelines, policies and procedures. As such the results demonstrate that most HEIs have research ethics documents located on their respective websites, which are accessible to the public and general users worldwide. The HEIs view research ethics as a matter of considerable importance, worthy of the substantial investment in terms of the staff time needed to produce the necessary processes and procedures, and the time and space to operate research ethics committees. Although these codes of research ethics in the various HEIs are not specific to educational research, there is some cross over on the substantive areas, such as respect for the rights of the human subject, informed consent and no harm clauses, similar to the items listed in Table 1.

\section{The ethical responsibility of the researcher}

In his studies of the ethics, conventions and standards of the academic system in the USA in terms of academic misconduct Decoo (2002) high lights the growing regulatory environment within which higher education institutes are required to operate purposeful codes of ethics. His attention is particularly focused on 'academic misconduct' relating to plagiarism and falsification. His research provides detailed accounts of both items in relation to both academic staff and student misconduct. In an Irish higher education context, probably the most cited case of plagiarism is the Flannigan versus University College Dublin High Court Case 1988.

Looking specifically at the educational research field and the respective codes and guidelines relating to research ethics as detailed in the literature reviewed, emerging themes and clusters of items can be identified. A principal theme that is identifiable is that of 'responsibility' of the researcher, and guidelines directing the researcher to consider questions such as the following.

Whom are you accountable to?

$>$ What are you liable for?

$>$ What is the legal setting?

$>$ How to present a truthful accessible account of the research process?

$>$ What is the most appropriate methodology to utilise?

$>$ Have you got the necessary know-how and knowledge to undertake this research?

Utilising this concept of 'responsibility' is clearly seeking to place the charge of accountability for 'actions' on the shoulders of the researcher. The researcher as the informed thinker, knowledgeable in the field of research and in many cases an expert, has a duty of care to those not so enlightened. ${ }^{[16]}$ The researcher has to give assurance that the research process will not be harmful to participants and indeed communities 
in the broader society. It places an onus on the researcher to produce trustworthy findings in accordance with scholarly conventions. The researcher as the agent of the research process is placed at the heart of the decision-making process. It is the researcher's burden to think of the wider political, social cultural issues and concerns that may arise before, during and after the research process. The researcher therefore has a duty to consider the potential risks and benefits of the research process and make an informed judgement on how best to proceed. The researcher cannot then blame another or pass on responsibility by claiming they were only following orders. When responsibility for the research process is centred on the researcher as the agent, then all action must be carefully calculated, for if there is a breach, fault, misleading claim, misconduct in the research process then the researcher must take the blame. As such, adopting a researcher responsibility approach can act as a powerful risk assessment tool which can inform the research process at the early stages of development.

The research process decisions a researcher makes depend on the researcher's world view or positionality. Scott and Usher (2003: 68-71) detail how researchers may base ethical decisions on their epistemological position, suggesting that there are three main models: 'covert research' (the researcher makes a decision not to disclose full information relating to the aims and purpose of research to participants), 'open democratic research' (the researcher decides to give participants access to information and a right to review data), 'autocratic research' (the researcher decides to protect the interests of participants but does not give a right to veto). This decision-making process could also be linked into the issue of gender. Giroux (1992: 61-82) provides an interesting discussion relating to feminism and questions of ethics. From that discussion one might question, are codes of ethics gender bound? In that, if society's structure is strongly influenced by patriarchy, would patriarchal values, norms and inequalities be both intrinsically and extrinsically embedded in codes of research ethics? Is there a need to have a distinct section in codes of ethics to deal with gender issues? There is a strong position for this, in that most of the prominent research figures - CEOs of companies that fund research and heads of research councils - are men, from this it could be suggested that the dominant voice recorded in codes of ethics is a male one. Riddell's paper in Burgess (2004 :77-97) sets out the research ethics dilemmas she faced, and her deliberations as a feminist carrying out research in an educational setting. She details five main areas where she reflected on her experience and developed her own solutions. They are: ethics and choice of method, ethics of access, power relations, analysis of data, and dissemination. In these example the researcher is being positioned into taking an active part in the decisionmaking process, the researcher as an agent in the social context needs to be critically aware of the external world.

Following on from this review of the literature, related research ethic items can be grouped under the following four researcher responsibility headings (see Table 3 for details).

Researcher's professional responsibility

$>$ Researcher's responsibility to the discipline(s)

$>$ Researcher's responsibility to the participant(s)

$>$ Researchers responsibility to report findings 


\section{Level3 - May 2008 -Issue 6}

Table 3 Typology of Educational Research Ethics: from a review of the educational research ethics literature

Educational Research Ethics Framework for D.Ed./Ph.D. students: Clustering of researchers' responsibilities and related categories

\begin{tabular}{|c|c|c|c|}
\hline $\begin{array}{l}\text { Researcher's professional } \\
\text { responsibility }\end{array}$ & $\begin{array}{l}\text { Researcher's responsibility to the } \\
\text { discipline }\end{array}$ & $\begin{array}{l}\text { Researcher's responsibility to } \\
\text { participants }\end{array}$ & $\begin{array}{l}\text { Researcher's responsibility to report } \\
\text { findings }\end{array}$ \\
\hline $\begin{array}{l}\text { Have the appropriate level of } \\
\text { competence and skill to carry out the } \\
\text { research }\end{array}$ & $\begin{array}{l}\text { Utilise peer review process to test ethical } \\
\text { concerns }\end{array}$ & $\begin{array}{l}\text { Deception should be avoided. If } \\
\text { considered necessary, then peer review } \\
\text { approval should be obtained and the } \\
\text { participant debriefed }\end{array}$ & $\begin{array}{l}\text { Report finding in an acceptable and } \\
\text { understandable fashion to the } \\
\text { audience(s) }\end{array}$ \\
\hline $\begin{array}{l}\text { Be mindful of issues relating } \\
\text { confidentiality. Where it is in the best } \\
\text { interests of the participant operate full } \\
\text { confidentiality }\end{array}$ & $\begin{array}{l}\text { Utilise appropriate research processes. } \\
\text { Where emergent theory/practice is used, } \\
\text { pilot, record and report findings and } \\
\text { access ethical issues }\end{array}$ & $\begin{array}{l}\text { Inform participants that they may } \\
\text { withdraw from research at any stage }\end{array}$ & $\begin{array}{l}\text { Do not exaggerate or manipulate the } \\
\text { findings }\end{array}$ \\
\hline $\begin{array}{l}\text { The research process should be carried } \\
\text { out in an honest and transparent } \\
\text { manner }\end{array}$ & $\begin{array}{l}\text { Report any issues or concerns that emerge } \\
\text { during the research that the discipline } \\
\text { may need to consider }\end{array}$ & $\begin{array}{l}\text { Explain; data usage (print, ICT, media), } \\
\text { lifespan of data, storage of data }\end{array}$ & $\begin{array}{l}\text { Do not manufacture or present false } \\
\text { data/findings }\end{array}$ \\
\hline $\begin{array}{l}\text { Appropriate professional integrity } \\
\text { should be maintained throughout the } \\
\text { research process }\end{array}$ & Protect the reputation of the discipline & $\begin{array}{l}\text { Provide feedback to participants and } \\
\text { debriefing sessions where necessary }\end{array}$ & $\begin{array}{l}\text { Findings should be disseminated } \\
\text { widely, in accordance to the } \\
\text { contractual agreements }\end{array}$ \\
\hline $\begin{array}{l}\text { Appropriate professional conduct } \\
\text { should be observed, particularly } \\
\text { pertaining to gender, culture, class, } \\
\text { race, ethnicity, sexual orientation, } \\
\text { religion }\end{array}$ & $\begin{array}{l}\text { Adhere to the research ethics code, } \\
\text { guidelines, practice }\end{array}$ & $\begin{array}{l}\text { Give full information and request } \\
\text { voluntary consent from participants }\end{array}$ & $\begin{array}{l}\text { Present true and accurate account of } \\
\text { research process and findings }\end{array}$ \\
\hline $\begin{array}{l}\text { Educational researchers should not act } \\
\text { to undermine the principle of } \\
\text { academic freedom }\end{array}$ & $\begin{array}{l}\text { Share new knowledge and experience } \\
\text { gained with the members of the discipline }\end{array}$ & $\begin{array}{l}\text { Explain who will have access to data, } \\
\text { whether it is restricted or open access }\end{array}$ & $\begin{array}{l}\text { Provide full information on how the } \\
\text { data was gathered, processed and the } \\
\text { theoretical framework used }\end{array}$ \\
\hline $\begin{array}{l}\text { Remain knowledge informed of the } \\
\text { discipline’s professional guidelines, } \\
\text { and the statutory law }\end{array}$ & $\begin{array}{l}\text { Contribute to the discipline's knowledge } \\
\text { by presenting findings to the members of } \\
\text { the discipline }\end{array}$ & $\begin{array}{l}\text { Cause no harm to participants, either } \\
\text { physically, psychologically and socially }\end{array}$ & $\begin{array}{l}\text { Be mindful of vested interests } \\
\text { seeking to influence reporting of } \\
\text { findings }\end{array}$ \\
\hline $\begin{array}{l}\text { Retain professional practice, by } \\
\text { training and upskilling }\end{array}$ & Plagiarism is unacceptable & Show respect to participants & $\begin{array}{l}\text { Be accountable for the data findings } \\
\text { you are presenting }\end{array}$ \\
\hline $\begin{array}{l}\text { Provide safe, secure storage of } \\
\text { participants' details, data, artefacts, } \\
\text { materials, (utilise appropriate ICT } \\
\text { protection) }\end{array}$ & $\begin{array}{l}\text { Special safeguards should be utilised } \\
\text { when working with vulnerable } \\
\text { participants }\end{array}$ & $\begin{array}{l}\text { Participants should be afforded } \\
\text { anonymity. In most cases this should be } \\
\text { an automatic procedure }\end{array}$ & $\begin{array}{l}\text { Defend data/findings from misuse } \\
\text { and inappropriate utilisation by } \\
\text { interested parties }\end{array}$ \\
\hline
\end{tabular}


The next stage to the review process is to identify appropriate items from the relevant educational research ethics material, and then make an informed judgement on the selection and categorising of items under the four principal researcher responsibility headings. The intent here is to develop a framework of concepts in educational research ethics that can be utilised to inform researchers who are considering undertaking, or are engaged in postgraduate, doctorate/Ph.D. level research projects. As with any framework it is not meant to be a solid inflexible structure but rather an outline of an area with component parts that can be fixed together in different patterns to suit the unique contexts and requirements of new research projects. This framework should be perceived as a thinking tool to stimulate probing and questioning during the initial stages of the development of a research process. For example when writing a research funding application, the researcher is obliged to consider the funder's 'Terms and Conditions' for funding research projects. ${ }^{[17]}$ It may be that these 'Terms and Conditions' are too restrictive, give too much control to the funder in relation to the research process and the reporting of findings. Indeed educational researchers should be mindful when entering into any contractual agreement with either a funder, university institute or private client, that ethical questions should be considered from the outset, relating to items such as; ownership, ${ }^{[18]}$ responsibility, conflicts of interest, reporting and so forth. Educational researchers should be vigilant against contractual agreements that seek to erode academic freedom, take ownership of copyright, control dissemination of the research process, or make a claim to the intellectual property.

While ethical consideration serves to protect the participants involved in the research process, there is no reason why the same ethical considerations should not be afforded to the researcher. This includes organisations such as universities, funding bodies, charities and commercial corporations, who sometimes draft 'Terms and Conditions' for research contracts which are more favourable to the interests of the organisation and can disenfranchise the researcher. After all research can produce new knowledge, and knowledge in the 'knowledge society' is a valuable commodity. Indeed it is viewed by some as an innovation driver to maintain competitive advantage. ${ }^{[19]}$ If this is the case, then the question should be how researchers can gain appropriate remuneration and even ongoing royalties from the commercialisation of their research by other parties. This is linked into the 'intellectual property' debate, a debate the World Trade Organisation (WTO) is seeking to gain international agreement on. ${ }^{[20]}$ In some cases the outcomes of research may have substantial financial potential, there are many examples in the ICT sector, were young postgraduate student researchers have turned a research project into a phenomenal financial success. Now some universities and commercial organisations that seed fund young researchers want the legal contractual framework in place to control and exploit the fruits of researcher's knowledge (intellectual property). By utilising an ethical framework to question the content of research funding contracts and seeking advice from representative associations', educational researchers can safeguard their own interests from the start of the research process. 
Level3 - May 2008 -Issue 6

Table 4 Utilising a critical ethics model in the research process, constructed from the literature reviewed

Towards a critical ethics model to inform the research process utilised in educational research in the Irish Higher Education sector

\begin{tabular}{l}
\hline Research process \\
\hline Review what is known: ontological assumptions
\end{tabular}

Review how it is known: epistemological assumptions Ethical framework

Locate what is known within the specific knowledge domain(s), identifying the dominant (official) knowledge paradigms

Critically evaluate the warrants and claims, for issues, claims and concerns relating to ideology, power, authority, dominance, inequality, gender, race, class, culture

Review data from multiple sources, academic literature, professional associations, and the official and alternative policy narratives, artefacts from for-profit and not-for-profit organisations, trade unions, memos, letters, brochures, publicity material, and media items

In avoidance of plagiarism and to give respect to the voice of others, record and acknowledge all data sources, giving fully traceability back to the source in accordance with academic convention

Make visible my own positionality and voice in the review of knowledge process and space

Planning: methodological considerations

Critically reflect on the intent of the research, the value of the research, the purpose of the research, the scope of the research

Identify the appropriate conceptual framework, methodology, methods and provide an explicit rational for their decision

Detail the characteristics of the sample set, paying particular attention to issue and concerns such as power, gender, race, culture, vulnerability

Produce a detailed and appropriate set of information material to invite and inform potential participant about the intended research process, giving assurance on the following items: confidentiality, anonymity, respect, right to with draw, right to review data, safe storage of data, usage of data, life span of data

Utilise a negotiation process to engage potential participant's informed consent, demonstrate sensitivity to the participant's requirements, if consensus (agreement) can't be reached after due process then agree to differ and disengage

Gathering data: specific types of methods

Demonstrate appropriate professional conduct and respect for the participant(s) during the data gathering process

Utilise professional judgement to facilitate and monitor the data gathering process, where risks to others are perceived or detected make appropriate intervention to reduce the level of risk, in some case the data gathering exercise may need to be halted

Utilise a location, space, material, equipment that the participant considers appropriate

Record the data exchange in the agreed manner, utilising appropriate professional techniques and equipment

Allow participants to review their data for accuracy, clarification before it brought forward to the data analysis stage of the research process

Do not engage in the fabrication; making up a sample framework, developing fictional participants, recording data from imagined participants

Respect the right of free speech, freedom of expression

Analysing data: specific types of methods

position of the source

Develop an appropriate coding systems which protects the identity of participants

Utilise a data analysis procedure (software, technique) that is fit-for-purpose, provide traceability links back to source data 
Level3 - May 2008 -Issue 6

\begin{tabular}{|l|l|}
\hline & $\begin{array}{l}\text { Do not engage in the falsification of data, making up or introducing data to fit a particular conclusion } \\
\text { Do not allow any third party external agent to assess data without the prior consent of participant(s) } \\
\text { Do not construct data in order to make exaggerated or false claims }\end{array}$ \\
\hline $\begin{array}{l}\text { Reporting findings, dissemination, locations, events, } \\
\text { presentations, types of communications channels }\end{array}$ & $\begin{array}{l}\text { Give a truthful and accurate account of the research process utilised, the data gathering procedure, the data interpretation process } \\
\text { and the findings } \\
\text { Disseminate findings to the academic communities via conferences, journals, repositories } \\
\text { Provide the participants with access to a copy of the final report } \\
\text { From critical reflection on the research process capture the learning and share this with the academic communities } \\
\text { Do not distort the finding or allow others to distort them, if they are challenged the research process utilise must be robust enough } \\
\text { to fend off such attacks } \\
\text { Monitor the usage and reporting of the finding by other, where they are misused by an agent, utilising the same channels send a } \\
\text { correction } \\
\text { The principle of academic freedom must be respected and defended through the research process }\end{array}$ \\
\hline
\end{tabular}




\section{Towards criticality in research ethics: personal positionality}

Let us move on to linking ethics as codified in the previously reviewed material (academic literature, government and international guidelines, professional associations, and documents, texts and artefacts extracted from electronic sources such as the websites of higher institutes of education and other digital repositories) into a critical ethics model ${ }^{[21]}$ to inform the research process utilised for this author's own D.Ed. research. ${ }^{[22]}$ See Table 4 for an outline of this informative process of relating theory into a practice. Practical examples of the utility of this approach are detailed in Appendices 1-4. Here I will endeavour to align elements relating to the field of contemporary critical theory ${ }^{[23]}$ such as power, ideology, official knowledge, ${ }^{[24]}$ authority, gender, inequality and the codes, guidelines and statements of the ethics narrative, within the stages of the particular 'research process', namely:

Reviewing what is known. (Ontological positions and epistemological claims are critically explored in relation to knowledge. The researcher adopts either an implicit or explicit position on the knowledge claims.)

$>$ Planning how to carry out the research. (Methodological frameworks, discipline paradigms are assessed and a best-fit conceptual framework is constructed. The researcher may engage with peers for critical comment. The researcher in accordance with their experience makes these decisions.)

$>$ Gathering data. (Methods are reviewed, tested and customised to suit research design. Tools and procedures are developed to facilitate the negotiated process of gaining access and consent. The researcher engages with peers for critical comment, evaluates the process and refines.)

$>$ Interpreting data and constructing meaning. (Specific methods are reviewed, additional training or skills updating may be necessary. A feedback loop is needed to authenticate data, evaluate process and make refinements. It is the researcher's responsibility to test the accuracy of the data and make sure they record it and analysis in a true fashion.)

$>$ Reporting findings. (The researcher considers dissemination strategy, channels of communication, knowledge repositories, locations and events, peer review opportunities and critically evaluates the process.)

A word of caution is needed. In practice the social research process is not a linear-stages structure that is orderly as detailed above, but rather it is a 'messy' process which engages with the social world. As this social interaction progresses, the researcher has to monitor events, refine processes and practice as required, engage in active problem solving, and record the evolving shape of the research process to inform future learning.

I am applying a critical ethics model as presented in Table 4 to question my positionality, construct an appropriate ethical approach to guide my methodology and methods in the D.Ed. dissertation research. ${ }^{[25]}$ In doing this I gave due consideration to the type of social research I have planned to undertake, the methodological issues, methods to be used and my relationship to the participants: these will be described in detail in Chapter 3 of the dissertation. The fundamental decision I made from the start was to use an open and transparent research process. I felt no need or desire for secrecy, either from my fellow D.Ed. students in TCD, colleagues in DIT doing 
doctoral studies in other institutes or colleagues working in the higher education sector in general. By utilising an open process it meant my emerging work was open to challenge from others. I found this quite useful; it assisted me in refining my thinking. In line with this starting approach I opted to endeavour to gain full informed consent from all participants whom I invited to participate in the research process. To facilitate this I produced several text-based information documents:

$>$ Letter of invitation

> Purpose: to provide a short note to introduce the research topic, invite participants to take part in the research and give assurance on ethical practice (see Appendix 1).

$>$ Request - consent form

$>$ Purpose: to provide a detailed document, setting out the following information - full contact details of researcher and supervisor, the title of the research project, the ethical guidelines for the research process - and a request for the participant to sign their consent (see Appendix 2).

$>$ Interview process and question items

$>$ Purpose: to explain how the interview process would work, what could be expected, and provide the question framework (see Appendix 3).

$>$ Brief CV

$>$ Purpose: to provide the participant with some general information about the researcher (this is in line with Yin's Case Study protocol).

By utilising this approach I sought to provide participants with enough general and specific information to make an informed decision on whether to participate or not in the research process. For this particular piece of social research I viewed each participant as an equal, who needed to be provided with adequate information before I began to negotiate with them in order to get their consent to participate. I approached potential participants directly and did not seek to leverage consent by approaching 'powerful gatekeepers', ${ }^{[26]}$ although I did invite some very senior managers to participate in the research process.

I gave each participant a commitment to confidentiality. The Irish Higher Education sector is quite small, and I am a practitioner as well as researcher in this sector. I undertook not to discuss participants' comments with other parties and only to present, analyse and discuss the agreed data text with others. Participants were also given the choice of anonymity, their data would be coded and their identity protected. In cases where participants were happy to be identified I maintained the right to withhold their identity if I considered it to be in their best interest.

On all material sent to participants I stressed that participants had the right to withdraw from the research process at any stage. Additional safeguards were also built into the ethical approach, such as the participants right to review and amend interview transcripts, the safe storage of material for a defined duration before its deletion, a statement on where, when and how the material would be used. Also I felt it was important to state that this was a not-for-profit piece of social research and the finished document would be freely accessible. By providing all this information I sought to alleviate suspicion ${ }^{[27]}$ in order to gain access while at the same time providing assurance to the participant that I would be conducting the research process in a professional fashion and adhering to contemporary academic standards and conventions. 
Utilising this critical ethical framework approach for the research process I endeavoured to show respect for the participant, minimise any perceived power imbalance, and create a professional mechanism to assist the research process approach and to demonstrate and uphold academic standards. As such, I reviewed best practice as a practitioner in higher education and developed a customised framework to suit the individual practical needs of the current research process. Thus I embedded ethics into this research process from the very start. By utilising ethics in the research process another level of sophistication and inquiry depth can be added to the social inquiry process. Ethical guidelines provide a contextual and conceptual background for the researcher to engage in critical thought relating to the research endeavour contemplated. This offers a rich source of material, which can stimulate reflective practice and enhance professionalism in the research process. 
Level3 - May 2008 -Issue 6

\section{Bibliography}

Allied Control Council (no date) 'The Trials of War Criminals before the Nuremberg Military Tribunals under Control Council Law No. 10 October 1946 - April 1949’, Vol. XI, available from The Congress Library USA at http://www.loc.gov/rr/frd/Military_Law/NTs_war-criminals.html (accessed 3 February 2008).

Allied Forces (1949) Trials of War Criminals before the Nuremberg Military Tribunals under Control Council Law No. 10', Washington, DC: US Government Printing Office Vol. 2, pp. 181-182; available online at http://www.cgirb.com/irbForms/NurembergCode.pdf (accessed 2 February 2008).

American Association for Public Opinion Research (2008) Code of Professional Ethics and Practice, available online at http://www.aapor.org/aaporcodeofethics?s=ethics (accessed 6 February 2008).

Apple, M. (2000) Official Knowledge: Democratic Education in a Conservative Age, London and New York: Routledge, 2nd edn.

Australian Government (1999) National Statement on Ethical Conduct of Research Involving Humans, available online at http://www.universitiesaustralia.edu.au/documents/publications/policy/statements/e 35.pdf (accessed 6 April 2008).

Australian Psychological Society (2007) Code of Ethics, available online at http://www.psychology.org.au/about/ethics (accessed 6 February 2008).

British Educational Research Association (1994) Ethical Guidelines, available online at http://www.bera.ac.uk/publications/pdfs/ETHICA1.PDF (accessed 4 February 2008).

British Psychological Society (1993) Code of Conduct for Psychologists, available online at

http://www.bris.ac.uk/Depts/DeafStudiesTeaching/dissert/BPS\%20Ethical\%20Gui delines.htm (accessed 4 February 2008).

British Sociological Association (1992) Statement of Ethical Practice, available online at http://www.staffs.ac.uk/schools/humanities_and_soc_sciences/sociology/doingsoc/e thgu2.htm (accessed 4 February 2008).

Burgess, R. (2004) The Ethics of Educational Research, London and New York: RoutledgeFalmer.

Busher, H. (2002) 'Ethics of Research in Education', in Coleman, M., and Briggs, A. (eds) Research Methods in Educational Leadership and Management, London: Sage.

Carroll, J. (2002) A Handbook for Deterring Plagiarism in Higher Education, Oxford: Oxford Centre for Staff and Learning Development.

Christians, C. (2005) 'Ethics and Politics in Qualitative Research', in Denzin, N., Lincoln, Y. (eds) The Sage Handbook of Qualitative Research, California, London, New Delhi: Sage, pp. 139-165.

Cohen, L., Manion, L. and Morrison, K. (2004) Research Methods in Education, New York, London: RoutledgeFalmer, 5th edn.

Cully, P. (2004) ;Plagiarism in Academic Project Work: An Overview, unpublished seminar paper available from Phil Cully at phil.cully@dit.ie.

Decoo, W. (2002) Crisis on Campus: Confronting Academic Misconduct, London: MIT Press.

Dublin Institute of Technology (2008) Ethics Committee, Guidelines and other Resources, available online at http://www.dit.ie/DIT/graduate/ethics/index.html (accessed 2 February 2008). 
Level3 - May 2008 -Issue 6

Education Studies Association of Ireland (2008) Homepage, online at http://www.esai.ie/Links.htm (accessed 3 February 2008).

Emanuel, E., Lemmens, T. and Elliot, C. (2006) 'Should Society Allow Research Ethics Boards To Be Run As For-Profit Enterprises?’ PloS Medicine, 3, (7) July: 941-944; available online at http://medicine.plosjournals.org/perlserv/?request=getdocument\&doi=10.1371\%2Fjournal.pmed.0030309 (accessed 12 February 2008).

European Educational Research Association (2008) Homepage, online at http://eera.educ.umu.se/web/eng/all/home/index.html (accessed 3 February 2008).

Flanagan versus University College Dublin Case (1988) Court transcript available online at

http://www.bailii.org/cgi-

bin/markup.cgi?doc=/ie/cases/IEHC/1988/1.html\&query=plagiarism+university\& method=all (accessed 7 March 2008).

Gallagher, G. (2005) 'An Examination of Ethical Issues Pertaining to Educational Research', DIT Level 3, May 2005, Issue 3, available online at http://level3.dit.ie/html/issue3 list.html (accessed 5 February 2008).

Gibbons, M., Limoges, C., Nowotny, H., Schwartzman, S., Scott, P. and Trow, M. (2005) The New Production of Knowledge: The Dynamics of Science and Research in Contemporary Societies, London and New Delhi: Sage Publications.

Giroux, H. (1992) Border Crossings, Cultural Workers and the Politics of Education, New York and London: Routledge.

Grix, J. (2004) The Foundations of Research, New York: Palgrave Macmillan.

Guba, E. and Lincoln, Y. (1989) Fourth Generation Evaluation, London and New Delhi: Sage.

Harris, R. (1999) The Plagiarism Handbook, Los Angeles: Pyrczak Publishing.

Hillier, Y. and Jameson, J. (2003) Empowering Researchers in Further Education, Stoke on Trent: Trentham Books.

Howe, K. and Moses, M. (1999) 'Ethics in Educational Research', Review of Research Education, 24: 21-60, available online at http://rre.sagepub.com/cgi/reprint/24/1/21 (accessed 3 February 2008).

Irish Government Publication (2006) Strategy for Science Technology and Innovation 2006-2013, available online at http://www.sciencecouncil.ie/reports/acsti060618/060618_asc_ssti_report_webopt. pdf (accessed 29 February 2008).

Lathrop, A. and Foss, K. (2000) Student Cheating and Plagiarism in the Internet Era: A Wake-up Call, Englewood, CO: Libraries Unlimited.

Lyotard, J. (1984) 'Research and its Legitimation through Performativity' in The Postmodern Condition: A Report on Knowledge, Minneapolis: Minnesota Press, pp. 41-47.

McNamee, M. and Bridges, D. (2002) The Ethics of Educational Research, London: Blackwell.

Marrow, R. and Brown, D. (1994) Critical Theory and Methodology, London and New Delhi: Sage.

Murphy, A. (2007) 'Ethics and Educational Research', lecture handout for postgraduate students, available on request from anne.murphy@dit.ie.

Nazi Regime Documents (1933-1945) 'The Final Solution’, The Jewish Virtual Library, A division of the American-Israeli Cooperative Enterprise, available online at http://www.jewishvirtuallibrary.org/index.html (accessed 4 February 2008).

Peters, R. (1966) Ethics and Education, London: George Allen and Unwin.

Pring, R. (2001) 'The Virtues and Vices of an Educational Researcher', Journal of Philosophy of Education, 35 (3): 407-421.

Sarantakos, S. (1998) Social Research, Basingstoke: Macmillan, 2nd edn. 
Level3 - May 2008 -Issue 6

Scott, D. and Usher, R. (2003) Understanding Educational Research, London and New York: Routledge.

Share, P. (2005) 'Managing Intertextuality: Meaning, Plagiarism and Power', MA thesis submitted to WIT, Chs 4 and 5, pp. 21-34; available at http://staffweb.itsligo.ie/staff/pshare/plagiarism/Plagiarism\%20thesis.doc accessed on 9 March 2008.

Simons, H. and Usher, R. (2000) Situated Ethics in Educational Research, London and New York: RoutledgeFalmer.

Stefani, L. and Carroll, J. (2001) 'A Briefing on Plagiarism', The Learning Teaching and Support Network, Generic Centre, series number 10.

Thompson, A. (1992) 'Ethics and Politics of Evaluation', Issues in Educational Research, 2 (1); available online at http://www.iier.org.au/iier2/thompson.html (accessed 5 February 2008).

Trinity College Dublin (2002) 'Good Research Practice', available online at http://www.tcd.ie/research_innovation/research/internal/documents.php (accessed 5 February 2008).

Trinity College Dublin (2005) 'The University of Dublin Calendar 2005-2006’, Part 1, Undergraduate Courses and General Information.

Wisker, G. (2005) The Good Supervisor, Basingstoke: Palgrave. 
Notes

1 Copies of the full records from 'The Trials of War Criminals before the Nuremberg Military Tribunals under Control Council Law No. 10 October 1946-April 1949', are contained in 15 volumes of court records. Electronic scanned versions of the original documents are available from The Library of Congress USA at http://www.loc.gov/rr/frd/Military_Law/NTs_warcriminals.html.

2 The Final Solution was not the enactment of one order or policy but rather it emerged during the period of the Nazi regime. See http://www.jewishvirtuallibrary.org/jsource/Holocaust/final.html for archival material.

3 Universal Declaration on Human Rights (1948) available online at http://www.un.org/Overview/rights.html.

4 Convention on Human Rights and Fundamental Freedoms (1949) available online http://conventions.coe.int/Treaty/Commun/QueVoulezVous.asp?NT=005\&CL =ENG.

$5 \quad$ Helsinki

Declaration

available

online

at http://www.cirp.org/library/ethics/helsinki.

6 Access to a vast amount of material relating to Ethics and Genetics, including policy tracking, international conventions and active debates is available at http://genome.wellcome.ac.uk/node30060.html.

7 The use of the typology here is taken from Grix (2004: 22) meaning a system of classification used to describe 'empirical phenomena by fitting them into a set of categories'.

8 See Emanuel et al. (2006) who discuss the pros and cons of Research Ethics Boards being run by either voluntary committees or for-profit enterprises. This paper raises important points about the potential conflict of interests.

9 The language usage of ethical guidelines displays an ideological position in terms of the researcher and researched: here the term human 'subject' is used, suggesting that a positivist approach is being utilised, where there is an unequal power balance in favour of the researcher or expert who does knowledgeable things to the subject. Homan's chapter in McNamee (2002: 2341) discusses this use of language, and suggests it is only in recent times that the researched have being termed 'participants' which suggests a more equitable and balanced power relationship.

10 See Seymer's chapter 'Qualitative Versus Quantitative Research Design' in McNamee (2002: 189-211) for a more extensive discussion of this topic.

11 This figure was obtained from the AERA website, under the heading 'About the AERA'; see http://www.aera.net/AboutAERA/Default.aspx?menu_id=90\&id=177.

12 This figure was obtained by telephoning BERA Head Office, Cheshire, UK, (Tel. 01625 504062) on 14 February 2008.

13 This figure was obtained from the EERA website; see http://eera.educ.umu.se/web/eng/all/members/current/index.html.

14 This data is a small 'snowball' sampling of URL links, a web search carried out on the 15 February 2008. ERA websites were opened and their establishment date sought. In some cases the websites would not open and in others navigation was problematic due to my deficiency in other languages, 
Level3 - May 2008 -Issue 6

thus the sample set is not intended to be definitive but rather as an example of growth trends.

15 For the full listing of HEIs that receive Irish Government funding administered through the Higher Education Authority see http://www.heanet.ie/about/members.html.

16 This can also be related to the discourse on 'knowledge power', politics and power, expert power. See Guba and Lincoln (1989: 117-142) for an interesting contribution to the ethics and politics debate.

17 The commissioning and funding of research projects is not value free. Funders have specific requirements or intentions for their involvement. Nixon's paper 'What is Evaluation After the MSC?' in Burgess (2004: 160-171) introduces this idea and the politics of the research project. In evaluation research projects where sometimes difficult decisions have to be made based on the research findings, researchers need to be fully aware of their remit and the potential outcomes.

18 Ownership here does not only relate to the findings of the research but the whole research process: issues such as intellectual property, and concerns about the use and in some cases the non-use of the findings. Researchers should consider joining an appropriate representative association and seek its professional advice before entering into contractual agreements. New/students researchers should always get external advice on contracts before they agree to sign, particularly if there is a potential commercial outcome to their research.

19 For a national policy perspective see the Irish Government Publication (2006: 34-37). For a theoretical perspective see Gibbons et al. (2005: 46-69).

20 See the World Trade Organisation (WTO) website for the top 10 criticisms of the WTO's approach to intellectual property and its responses (http://www.wto.org/english/thewto_e/minist_e/min99_e/english/misinf_e/05k illin_e.htm).

21 The use of the word 'model' is linked to Grix (2004: 20-21). A model is a way of representing something; it can be used as 'a descriptive or explanatory device', and is a useful mechanism to visualise abstractions, concepts and interrelationships.

22 This research focuses on the Irish Higher Education sector, and adopts both numeric and non-numeric conceptual approaches, supported by mixed method instruments.

23 For more information on contemporary critical theory see Morrow and Brown (1994: 3-30).

24 The term 'official knowledge' comes from Apple (2000: 1-15) and the concept here of regulating official knowledge from Apple (2000: 61-89).

25 I am in the $3^{\text {rd }}$ year of the D.Ed. programme in TCD. The title of my dissertation is 'The Dynamics of Human Capital and the Labour Process in Higher Education, Power, Compliance and Resistance: A Critical Theory Perspective'.

26 See McNamee (2002: 23-41).

27 Wisker (2005: 117-118) provides some examples of where the subjects of applied research are suspicious of the researchers. In some cases the researchers were viewed as government spies. 
Level3 - May 2008 -Issue 6

\section{Appendix 1}

Letter of invitation

Dear

I am carrying out an initial series of research interviews with higher education organisations and representative bodies for my D.Ed dissertation in TCD. The working title of this research is, 'The Dynamics of Human Capital and the Labour Process in Higher Education: Power, Compliance and Resistance; A Critical theory Perspective'. (Please find attached some additional information; Interview items, Request \& Consent form, Short CV).

I would like to invite you to participate in a recorded semi-structured interview session, duration about 30-45 minutes, at a location of your choice. Details on ethical guide lines and the interview process are attached; I would just like to reemphasis two important points here;

(1) Participants will receive a copy of the transcript from the interview to correct and authenticate,

(2) A Participant who consents to take part in the research may withdraw from this research project at any stage.

Please do not hesitate to contact me for further information.

Regards

Aidan Kenny

Project Manager,

DIT Skills Research Initiative.

Bolton Street Campus.

81 Capel Street.

Dublin 1.

Ireland.

Tel. 0035314023757

Mob. 0861048449

Email aidan.kenny@dit.ie 


\section{Appendix 2}

\begin{tabular}{|c|c|c|}
\hline \multicolumn{3}{|c|}{\begin{tabular}{|l} 
Research Interview Request and Consent Form \\
\end{tabular}} \\
\hline \multirow{6}{*}{ 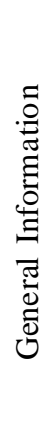 } & $\begin{array}{l}\text { Research } \\
\text { student }\end{array}$ & $\begin{array}{l}\text { Aidan Kenny, Project Manager, Skills Research Initiative. } \\
\text { DIT, Bolton St. Campus, 81 Capel St., Dublin 1. } \\
\text { Tel. } 402 \text { 3757, Mob. } 086 \text { 1048449, Email, aidan.kenny@dit.ie }\end{array}$ \\
\hline & Supervisor & $\begin{array}{l}\text { Dr. Peter Conroy, Lecturer } \\
\text { School of Education, Arts Building, Trinity College Dublin. D.1. } \\
\text { Tel. } 8963583 \quad \text { Email conroypc@tcd.ie }\end{array}$ \\
\hline & Programme & Doctor in Education (D.Ed) \\
\hline & College & Trinity College Dublin. \\
\hline & Purpose & Gathering of data for D.Ed dissertation \\
\hline & $\begin{array}{l}\text { Dissertation } \\
\text { title }\end{array}$ & $\begin{array}{l}\text { The Dynamics of Human Capital and the Labour Process in Higher } \\
\text { Education. }\end{array}$ \\
\hline
\end{tabular}

I agree to participate in a recorded interviewed session with the above named research student under the following terms and conditions:

$>$ Consent; the participant may withdraw consent to be interviewed or the usage of recorded material at any stage of the research process.

$>$ Confidentiality; the original recordings will be made available upon request to my supervisor named above and the members of the examination panel.

$>$ Anonymity; the authenticity of research is higher were the identity of the participant is detailed, however it is acceptable for participants to request for their identity to hidden, the author may use their own academic judgement to hide a participants identity even if the participant agreed to be named.

$>$ Review; the participant has the right to review the transcription from the interview and insert clarifications or corrections were necessary.

$>$ Purpose; the recorded material will be utilised by the research student for scholarship and research relating to the pursuit of his D.Ed in TCD.

$>$ Analysis; the recorded material will be transcribed, coded, categorised and interpreted in accordance with scholarly convents.

$>$ Publication; extracts or the full content of the analysed material may appear in the dissertation, conference presentations, papers submitted to academic journals.

$>$ Availability; extracts or the full content of the analysed material will be accessible from, the TCD library dissertations section, conference papers, academic papers and certain electronic repositories.

$>$ Security; all recorded material will be stored in a secure place in a locked cabinet, the storage of electronic data will be password protect.

$>$ Storage; recordings will be stored for three years post qualification, there upon they will either be deleted or permission for an extension will be sought from the participant.

$>$ Not-for-profit; this is a non-commercial piece of academic research, the author will disseminate the findings on a cost neutral basis.
Participants signature
Date / /2008

\begin{tabular}{l|l}
\hline First name Address & Tel. \\
\hline Surname & \\
\hline & Email
\end{tabular}

Thank you for consenting to participate in this piece of academic research. 


\title{
Level3 - May 2008 -Issue 6
}

\section{Appendix 3}

\author{
Interview items and process
}

\section{Dear Participant,}

Thank you for agreeing to take part in this piece of academic research by signing the consent form. The format for this piece of research will consist of a recorded 'semi-structured interview', this should take about 30-45 minutes to complete.

Some general information:

This research is confined to the general domain of higher education, with a specific focus on the dynamic relationship between academic practice and policy and strategy. The preliminary intention is to gather data from several different perspectives, students, academics, managers, policy makers, representative organisations and other agents. Participants can state their own particular perspective.

The research process:

Before the interview: Participants are asked to engage in critical reflection from their own experience of any of the items listed below in the interview schedule prompt list. Participants can chose to focus on several items and new items can be added if they are considered to be relevant.

During the interview: Participants will be prompted to provide, descriptions, explanations and sources of relevant information. Participants will also be asked to evaluate areas of major interest to them, and consider categorising them into the following three criteria:

$$
\begin{array}{ll}
\text { 'Issues' - } & \text { area that you think needs to be and can be resolved. } \\
\text { 'Concerns' - } & \text { problem area that needs resolving but is extremely difficult. } \\
\text { 'Claims' - } & \text { areas of agreement and examples of good practice. }
\end{array}
$$

After the interview: A transcript of the interview will be sent to each participant to check for accuracy and add clarifications; the returned transcript will then become the data source for analysis.

\begin{tabular}{|ll|}
\hline Main items & Subcat egories \\
& Teaching practice (students, lectures, workshops, facilities etc.) \\
& Programme development / design / review \\
& Assessment practice (formative / summative / continu ous / etc.) \\
& Systems (Quality assurance, modularisation, semesterisation etc.) \\
& Scholarship and professional practice \\
\hline Research & Research activities \\
& Autonomy to pursue research \\
& Research funding \\
& Research reviews \\
& Scholarship and professional practice \\
Other duties & Management (systems, units, programmes, projects etc.) \\
& Administration (records, reports, communication, storage etc.) \\
& Co-ordination (students, team, programmes, project etc.) \\
\hline Career & Entry (selection process, induction, contract type, grade) \\
& Career (tenure, remuneration, promotion, opportunities, training) \\
Voluntary & Exit (information, pension, planning, succession) \\
activities & Relating to work (teaching, research, etc) \\
\hline Your items & Yourernal focus (sports, community, charity etc) \\
\hline & \\
& \\
& \\
\end{tabular}

Thank you for giving up your time and contributing to this piece of academic research. 